OPEN ACCESS

Edited by:

Jason Trubiano,

University of Melbourne, Australia

Reviewed by:

Tao Zhang,

Xi'an Jiaotong University, China Jeremy McComish,

Royal Melbourne Hospital, Australia

${ }^{*}$ Correspondence:

Benjamin D. McNeil benjamin.mcnei@northwestern.edu

Specialty section: This article was submitted to Alloimmunity and Transplantation, a section of the journal

Frontiers in Immunology

Received: 05 March 2021

Accepted: 15 June 2021

Published: 06 August 2021

Citation:

McNeil BD (2021) MRGPRX2 and

Adverse Drug Reactions.

Front. Immunol. 12:676354. doi: 10.3389/fimmu.2021.676354

\section{MRGPRX2 and Adverse Drug Reactions}

\author{
Benjamin D. McNeil ${ }^{\star}$
}

Division of Allergy and Immunology, Feinberg School of Medicine, Northwestern University, Chicago, IL, United States

Many adverse reactions to therapeutic drugs appear to be allergic in nature, and are thought to be triggered by patient-specific Immunoglobulin E (IgE) antibodies that recognize the drug molecules and form complexes with them that activate mast cells. However, in recent years another mechanism has been proposed, in which some drugs closely associated with allergic-type events can bypass the antibody-mediated pathway and trigger mast cell degranulation directly by activating a mast cell-specific receptor called Mas-related G protein-coupled receptor X2 (MRGPRX2). This would result in symptoms similar to lgE-mediated events, but would not require immune priming. This review will cover the frequency, severity, and dose-responsiveness of allergic-type events for several drugs shown to have MRGPRX2 agonist activity. Surprisingly, the analysis shows that mild-to-moderate events are far more common than currently appreciated. A comparison with plasma drug levels suggests that MRGPRX2 mediates many of these mild-to-moderate events. For some of these drugs, then, MRGPRX2 activation may be considered a regular and predictable feature after administration of high doses.

Keywords: MRGPRX2 receptor, anaphylaxis, mast cells, perioperative anaphylaxis, morphine, atracurium, vancomycin, rocuronium

\section{INTRODUCTION}

Acute adverse reactions to therapeutic drugs are those which occur within minutes to hours of drug exposure, and many of these present clinically as allergic episodes $(1,2)$. Mild-to-moderate symptoms include rash, erythema, pruritus, tachycardia, local tissue swelling, moderate bronchospasm, transient hypotension, and gastrointestinal distress $(3,4)$. The most extreme of these reactions are classified as "anaphylaxis" and can be life-threatening; these include more severe hypotension, bronchospasm, and tissue swelling, and even collapse of the cardiovascular system $(3,4)$.

Most of these are assumed to be driven by activation of mast cells by drug-specific Immunoglobulin E (IgE) antibodies, which are called Type I immediate hypersensitivity reactions $(1,2,5)$. Prior exposure to the drug, or to a compound with a structurally similar element, stimulates production of antibodies that recognize the drug or a conjugate formed when the drug or a metabolite binds to an endogenous protein. These antibodies then associate with 
high-affinity IgE receptors on the surface of mast cells in a manner that leaves their drug-binding sites free. When a drug recognized by the antibodies is administered, it (or the conjugate) binds to multiple antibodies at the same time. This brings the IgE receptors associated with the antibodies into prolonged close contact, triggering activation of the receptors and the release of mediators like histamine that generate the allergic responses (6).

Another cause of acute mast cell activation has been proposed, in which drugs trigger reactions very similar to Type I events - but without the need for antibodies or immune priming - by activating mast cells directly through a receptor called Mas-related G proteincoupled receptor X2 (MRGPRX2). MRGPRX2 is a seven transmembrane $G$ protein-coupled receptor which is expressed almost exclusively by a subset of mast cells that populate connective tissues like the skin $(7,8)$. It is classified as an orphan receptor (9), meaning that the ligand(s) it is intended to recognize has not been determined. However, multiple screens with hundreds of small molecules, peptides, and proteins have established that it is responsive to a wide range of molecules, and that the overwhelming majority of them carry a net cationic, or positive, charge $(8,10-14)$. A recent review identified that most also have bulky hydrophobic groups, perhaps to increase affinity for plasma membranes (15). In 2015 a study reported that several therapeutic drugs with cationic groups, all of which induce high rates of allergic-type reactions, are agonists for MRGPRX2 (12). Moreover, activation of a cell line called LAD2, which has properties similar to human mast cells and often is used as a surrogate because primary cells are very difficult to extract, was dependent upon MRGPRX2 (12). Other drugs capable of activating MRGPRX2 have since been found, many of which also trigger allergic-type events. This finding raises the possibility that side effects that appear to be Type I - i.e., allergic and IgE-mediated - may in some cases arise instead from direct activation of mast cells through MRGPRX2. Such events have been called "pseudo-allergic" or "anaphylactoid" to distinguish them from true allergies. All events that present as allergic episodes will be referred to as "allergic-type" in this review, as the etiology is not always clear.

This review will present an analysis of the frequencies of allergic-type events for many drugs/MRGPRX2 agonists that are particularly closely associated with such events. Calculated $\mathrm{EC}_{50}$ values for MRGPRX2, compiled from several studies, are presented in Table 1 (12-14, 16-19). Two specific issues are addressed for each drug: 1.) whether the mild-to-moderate events truly are mast cell-mediated; and 2.) whether

TABLE 1 | Calculated EC50 values for selected MRGPRX2 agonists.

\begin{tabular}{lcc}
\hline Name & EC $_{50}$ & Reference \\
\hline Vancomycin & $\sim 60$ micrograms $/ \mathrm{ml}$ & $(14)$ \\
Atracurium & $28.6 \mathrm{micrograms} / \mathrm{ml}$ & $(12)$ \\
Mivacurium & $39 \mathrm{micrograms} / \mathrm{ml}$ & $(16)$ \\
Cisatracurium & $103 \mathrm{micrograms} / \mathrm{ml}$ & $(17)$ \\
Rocuronium & $261 \mathrm{micrograms} / \mathrm{ml}$ & $(12)$ \\
Morphine & $4.5-7$ micromolar & $(13,18,19)$ \\
Ciprofloxacin & $1.3-2.0$ micrograms $/ \mathrm{ml})$ & $(12)$ \\
Levofloxacin & $6.8 \mathrm{micrograms} / \mathrm{ml}$ & $(12)$ \\
Moxifloxacin & $22.7 \mathrm{micrograms} / \mathrm{ml}$ & $(12)$
\end{tabular}

MRGRPX2 involvement is supported. The first issue is important because, while anaphylaxis elicits a stereotyped and coordinated set of symptoms with a clear mast cell origin, the milder events only include some of these, and mast cell activation is not the only possible cause of the symptoms. The second issue, of whether MRGPRX2 is involved, is impossible to prove without specific antagonists. However, if events are much more common only when plasma levels are high enough to activate MRGPRX2, it certainly supports a role for this receptor. Therefore, plasma concentrations are provided for each drug. A more detailed discussion on methods of distinguishing IgE from MRGPRX2 or other non-IgE origins is provided in Section II.

The most surprising finding from this analysis is that mild-tomoderate allergic-type events can be very frequent, much more so than generally presumed. These events generally are neglected in favor of anaphylactic episodes, which are much more serious but are extremely rare. In contrast, mild-to-moderate events have been reported to occur in a majority of patients at some drug dosages. These are not trivial and may have serious impacts on health when patients already are highly compromised. Peak drug plasma concentrations support MRGPRX2 involvement in these events for several drugs; this suggests that MRGPRX2 activation might be considered a common, not a rare, feature when these drugs are administered.

\section{DETERMINATION OF IGE- VS. MRGPRX2- MEDIATED MAST CELL ACTIVATION}

A pressing issue in the field is how to determine whether mast cell activation is mediated by IgE or MRGPRX2 when a patient has suffered an allergic-type event due to a drug that is an MRGPRX2 agonist. These drugs also may be immunogenic, so simply exhibiting MRGPRX2 agonism does not rule out IgE. Technically, distinguishing between these is not yet possible because there are no biomarkers that reliably identify or exclude one or the other mechanism, such as a mediator only released after stimulation of one but not the other receptor. However, specific measurements can be made that support the involvement of each pathway.

\section{MRGPRX2 Involvement}

MRGPRX2 should be suspected if an event is only observed at concentrations high enough to activate the receptor, and resolves when the concentration drops below this. As described in detail in th next section, the drug concentrations needed to activate MRGPRX2 are very high and only achieved transiently for most drugs. Many allergic-type reactions also are very transient and only occur at very high drug concentrations. In contrast, there is a widespread assumption that IgE-mediated mast cell activation occurs even at very low concentrations of an antigen - for example, food allergies only require miniscule amounts of foodthough this is not proven for every allergy. Another factor is that mediator release after IgE-driven mast cell activation persists for much longer than after antibody-independent mast cell stimulation (20), so events that are short-lived are less likely to be IgE-driven, 
especially if they only occur at high drug concentrations and disappear when plasma or tissue concentrations drop below $\mathrm{EC}_{50}$ values for MRGPRX2.

$\mathrm{EC}_{50}$ values for MRGPRX2 can be used to determine whether plasma or tissue drug concentrations are high enough to activate the receptor. However, several additional factors should be considered when evaluating these. First, plasma concentration measurements may not reflect concentrations in some tissues; specific examples are discussed in the fluoroquinolones and neuromuscular blocking drug sections. Second, $\mathrm{EC}_{50}$ values must be taken in context, as caveats exist. The values were calculated for the most common MRGPRX2 variant, but dozens of others with slightly different amino acid compositions, due to natural variations in the coding DNA, have been identified $(21,22)$. These sometimes have altered properties; most of the ones characterized are loss-of-function, but ones with enhanced signaling have also been reported $(23,24)$. It is quite possible that alleles that respond to much lower drug concentrations are expressed by some patients, and if so, $\mathrm{EC}_{50}$ values for those variants should be used instead. Also, MRGPRX2 expression levels vary tremendously between subjects (25), and those with abnormally high expression may also respond to low drug concentrations, even when the canonical receptor variant is expressed. Another consideration is that $\mathrm{EC}_{50}$ values usually are calculated in cell lines, not in primary cells. Finally, concurrent illnesses may either enhance or reduce mast cell responsiveness, or how tissues respond to mast cell mediators. An example is provided below in the vancomycin section, in which bacterial infections appear to dramatically reduce systemic mast cell responses. On the other hand, patients with chronic spontaneous urticaria appear to have much stronger responses to MRGPRX2 agonists (26). This is an emerging topic and more research needs to be performed, but it is clear that comorbidities can have a profound influence on allergic-type reactions.

\section{IgE Involvement}

IgE-mediated mast cell activation should be suspected when events occur at low drug concentrations, when the events are of long duration, or when drug-specific IgE titers are high. Four tests are recognized by the World Allergy Organization to help determine whether a patient has drug-specific IgE antibodies: a skin prick test, intradermal injection of the drug, plasma or serum IgE quantification, and basophil activation tests (27). Protocols are not standardized, and interpretation of the results can be quite controversial $(28,29)$. Of these, skin prick and intradermal injection tests are, by far, the most common methods for identifying IgE involvement. The concept behind them is that concentrations are too low to activate MRGPRX2, but are sufficient to trigger IgE reactions. However, concentrations are not standardized and in many cases likely are enough to activate MRGPRX2 - for instance, a commonlyused skin prick test concentration for morphine and atracurium is $1 \mathrm{mg} / \mathrm{ml}$ (30), dozens of times higher than their $\mathrm{EC}_{50}$ values for MRGPRX2 activation (Table 1). Intradermal concentrations generally do not exceed these values, though morphine is recommended at 10 micrograms $/ \mathrm{ml}$, over 5 times higher than its $\mathrm{EC}_{50}$ value. As mentioned above, MRGPRX2 variants may have greater sensitivity and may trigger signaling at even lower drug concentrations. Even when several tests are used, the results can be equivocal. In one study, all four tests were conducted in each of 140 instances of anaphylaxis after administration of the neuromuscular blocker rocuronium (31). Strikingly, the tests all were in agreement in less than $15 \%$ of the cases. This is not meant to imply that IgE tests are not useful, only that they are not yet optimized, and that tests for MRGPRX2 involvement should be conducted, as well.

Unfortunately, the assays described for MRGPRX2 and IgE essentially never are conducted together. Plasma drug concentrations and MRGPRX2 allele analysis are almost exclusively limited to controlled experiments in which mild-tomoderate but not anaphylactic events are observed. Conversely, IgE tests are used as a diagnostic only after anaphylactic episodes. Until they are all performed in tandem, even a perfect IgE test cannot rule out MRGPRX2; likewise, evidence of extraordinarily high drug concentrations cannot rule out IgE. It even seems quite plausible that both can operate together in some cases. It is hoped that future studies with a more comprehensive approach will be undertaken to help clarify this matter, particularly in cases of anaphylaxis.

\section{ALLERGIC-TYPE ADVERSE EVENT FREQUENCIES AND ANALYSIS}

This section summarizes and analyzes the available data on allergictype event frequency for several drugs known to have MRGPRX2 agonist properties. It also discusses evidence for and against a mast cell origin for these events, as well as peak plasma drug concentrations to help evaluate whether MRGPRX2 plays a role when mast cells are involved. Plasma drug concentrations are almost totally unknown in patients who have suffered anaphylactic episodes, so correlations cannot be made for these events.

\section{Vancomycin}

Vancomycin is a glycopeptide antibiotic used for difficult-totreat Gram-positive bacterial infections like methicillin-resistant Staphylococcus aureus $(32,33)$. It is given orally or, more frequently, intravenously as a slow infusion, and is closely associated with allergic-type reactions - often regrettably described as "Red Man Syndrome" - that begin during or shortly after infusion (34).

\section{Allergic-Type Event Frequency and Mast Cell Dependence}

Allergic-type reactions are the most common side effects of vancomycin, and are characterized by erythema of the head and neck, hypotension, tachyphylaxis, pruritus, and occasional angioedema $(33,35,36)$. These usually are associated with elevated plasma histamine (37-41), and often can be mitigated by antihistamines (42-46), confirming mast cell involvement in these reactions.

The reported frequency of allergic-type reactions is highly variable, with most studies reporting either $5 \%$ or less [e.g (47$54)$ ] or over $70 \%$ [e.g (38-40, 42, 46, 49, 55-57)]. No systematic differences in dosage exist between the high and low incidence studies, suggesting that other factors were responsible for this 
vast disparity. Notably, with very rare exceptions $(43,58)$, the studies reporting high incidence rates were conducted specifically to examine side effects, while the studies with low rates were designed to assess antibacterial efficacy. It is plausible that the different aims resulted in different thresholds for what constituted a medically relevant side effect.

Another difference between the high and low incidence studies is the makeup of the study populations. The high incidence studies examined healthy subjects or hospital patients without infections, while the low incidence studies were almost all of patients with severe bacterial infections. Mast cells can be activated by bacteria (59), and it is possible that persistent activation during infection leads to mast cell desensitization to further stimuli, and/or systemic desensitization to mast cell mediators. In support of this, one small study compared responses in healthy volunteers to those in infected patients, and found that no infected patients had any reactions, while nearly all of the healthy controls did (49). No definitive conclusion can be drawn yet, but the inverse correlation between infection and mast cell responsiveness appears to be quite strong.

In a massive study of over four million patients given vancomycin, anaphylaxis was reported to occur with a frequency of $0.018 \%$, or approximately 1 in 5000 (54).

\section{Peak Plasma Concentrations and Potential MRGPRX2 Involvement}

Vancomycin is a weak agonist, with a calculated $\mathrm{EC}_{50}$ of about 60 micrograms/ml (14). Recorded peak plasma levels of vancomycin cluster around the 30-50 micrograms/ml range, which is enough to activate mast cells but not to a large extent. Patients with more severe reactions may have plasma levels on the upper end of this range - indeed, levels exceeding 70 micrograms/ml have been reported (55). Importantly, most measurements were taken after the infusion was complete and they may underreport the actual peak. Small differences in concentration are important when considering MRGPRX2 activation, as the reported dose-response curve in cell lines is very steep (14) and slight changes can have large effects. For example, in one study, reducing the average peak concentration from 65.7 to $40.3 \mathrm{micrograms} / \mathrm{ml}$ was sufficient to completely abolish all allergic-type reactions (55). Plasma drug levels and MRGPRX2 allele expression were not recorded in the large study that calculated anaphylaxis rates (54), so no correlations are available.

\section{Atracurium, Cisatracurium, and Mivacurium}

These all are non-depolarizing neuromuscular blocking drugs (NMBDs). NMBDs are routinely used during surgical procedures to facilitate tracheal intubation of breathing tubes, and to reduce aberrant muscle activity during the surgeries. They bind to and block acetylcholine receptors expressed by muscles, preventing innervation by nerves (60). High doses of atracurium and mivacurium are associated with allergic-type side effects (61); these are much less frequent after cisatracurium administration $(62,63)$, which may be due to the fact that relatively low doses are used.

\section{Allergic-Type Event Frequency and Mast Cell Dependence}

Non-depolarizing NMBDs are associated with flushing, erythema, and hypotension (61). Preclinical studies suggested that high doses of atracurium would cause hypotension and histamine release in patients (64). This was indeed the case - after rapid injection of 0.5 $\mathrm{mg} / \mathrm{kg}$ or more, elevated histamine levels in the plasma were recorded (65-69), drops in mean arterial blood pressure (MAP) of at least $20 \%$ were observed in most studies, and this could be blocked by pre-treatment with a combination of $\mathrm{H} 1$ and $\mathrm{H} 2$ histamine receptor antagonists (65-68). Flushing or erythema also were blocked in studies that monitored this $\operatorname{AE}(66,69)$. The choice of antihistamine may be important, as some can counteract their own effects by blocking the enzyme that breaks down histamine, which would elevate histamine levels (65). One study demonstrated that the anesthetic thiopental, commonly used with atracurium, also can cause a drop in MAP, and suggested that this is the primary reason for the drop (69). However, this does not explain the cases where thiopental was not used (68) or was administered well before atracurium $(66,67)$, nor does it explain why the drop in MAP could be abolished by slowing down the atracurium injection time (65, 66), which would produce a lower peak plasma concentration. Taken together, the data strongly suggest that the immediate drop in MAP and cutaneous allergic-type effects, the primary side effects of atracurium, are caused by mast cell activation.

Mivacurium injection is associated with elevated plasma histamine levels, flushing/erythema, and drops in mean arterial pressure (MAP) of greater than $20 \%$, which all correlate with the speed of injection and drug dose. Elevated histamine levels were frequently observed when measured, sometimes in more than $50 \%$ of patients (70-73). Flushing/erythema has been observed in from $6 \%$ to $73 \%$ of patients $(70-72,74-82)$. MAP changes also occur at a lesser frequency, from $0 \%$ to $50 \%(70,72,73,77$, 80-83). Studies that examined all at once found that MAP changes nearly always were accompanied by flushing and histamine release $(70,73,78)$. Antihistamines block all these effects $(72,78)$. It should be noted that occasional studies only reported average changes in histamine levels and/or mean arterial pressure, which sometimes did not achieve significance as a group $(71,79,82,84)$. This does not mean that zero patients in the group suffered from an AE. The heterogeneity of responses, compared to atracurium, likely stems from the variety of mivacurium doses and speeds of injection.

Cisatracurium is very rarely associated with allergic-type side effects, with incidence rates of $0.5 \%$ or less $(62,63)$, even in patients with existing cardiovascular morbidity (85). Elevated plasma histamine levels, though usually mild, have been recorded after high doses $(0.2 \mathrm{mg} / \mathrm{kg}$ or more) of cisatracurium in approximately $5-10 \%$ of patients, so it is possible that the allergic-type events are indeed mast cell-mediated (86-89).

Recent studies have estimated the incidence of atracuriuminduced anaphylaxis at approximately 1 in 20,000-50,000 (90-93). Anaphylactic episodes after cisatracurium administration are exceedingly rare, as low as 1 in 250,000 (92), though data are not common and estimates are not necessarily representative. Anaphylaxis after mivacurium was estimated as occurring in less 
than 1 in 1,000,000 administrations in a recent study (90), though, as with cisatracurium, data are relatively sparse, compared to rocuronium and atracurium. Plasma drug levels and MRGPRX2 allele data are not available for these events.

\section{Peak Plasma Concentrations and Potential MRGPRX2 Involvement}

Peak recorded plasma concentrations after rapid atracurium injections are usually less than $10 \mathrm{microgram} / \mathrm{ml}$ range, even when high concentrations of $0.5 \mathrm{mg} / \mathrm{ml}$ or more are administered $(94,95)$. This is lower than the calculated $\mathrm{EC}_{50}$ for MRGPRX2 of 28.6 micrograms/ml (12), and it is not clear from intradermal injection studies that mast cells respond to lower concentrations (96). However, even though measurements were taken 1-2 minutes after injection, there is reason to believe that these are not truly peak plasma or interstitial concentrations. Two studies found that extending injection times from 5-30 seconds to 75 seconds was sufficient to abolish most AEs $(65,66)$. This suggests that rapid injections produce plasma or interstitial concentrations somewhere in the body that are enough to activate mast cells; these are achieved for only several seconds and a very slight reduction in injection speed is enough to prevent this. These might not be captured in blood samples, even shortly after injection; notably, the cited pharmacokinetic studies did not include information about injection speed.

Peak reported plasma concentrations of the combined isomers of mivacurium cluster in the 3 to $10 \mathrm{micrograms} / \mathrm{ml}$ range when measurements are taken within a few minutes of injection (97-101). These also are too low for efficient activation of MRGPRX2, if the recorded $\mathrm{EC}_{50}$ of $39.0 \mathrm{micrograms} / \mathrm{ml}$ is accurate (16), and skin tests provide little evidence for activation at lower concentrations. Interestingly, 10-15 second injection times produced far more AEs than when administration was 30 seconds or more $(70,77,80)$. This suggests that, as with atracurium, the true peak plasma and/or interstitial concentrations may be missed by the recordings.

Data on peak cisatracurium plasma concentrations are relatively scarce, but usually are less than 2 micrograms $/ \mathrm{ml}$ (102, 103). This is far below the calculated $\mathrm{EC}_{50}$ of 103 micrograms/ml (17). These seem to be too far apart to consider any side effects to be MRGPRX2-related. However, skin reactions to intradermal cisatracurium have been observed at $12 \mathrm{micrograms} / \mathrm{ml}(104,105)$, and LAD2 cell activation by cisatracurium is dependent on MRGPRX2 (17), so it is possible that the $\mathrm{EC}_{50}$ for primary mast cells may be lower.

\section{Rocuronium}

Rocuronium is a member of the aminosteroid group of NMBDs that, like atracurium, acts as a muscle nicotinic receptor antagonist (60). Its onset is only slightly slower than the fastest-acting NMBD, succinylcholine, while its duration is longer (106). One attractive reason to use rocuronium is that its effects can be reversed rapidly by administering sugammadex, which binds to and inactivates rocuronium (107) and allows for precise control over paralysis. Unlike atracurium, very few adverse events related to off-target activity like mast cell degranulation are reported (106, 108-111). Somewhat surprisingly, the incidence of anaphylactic reactions, while still rare, has been estimated in some studies as being higher after administration of rocuronium that of most other NMBDs (91, 93).

\section{Allergic-Type Event Frequency and Mast Cell Dependence}

The most commonly-reported acute side effect specifically associated with rocuronium is tachycardia (112). Tachycardia, or increase in heart rate, has been observed with histaminereleasing drugs, but in the case of rocuronium, this is thought to be caused by off-target block of acetycholine receptors that regulate cardiac pacemaker activity (112). In fact, elevated histamine levels are extremely rare $(72,73,113)$ and immediate hypersensitivity events are not observed in the vast majority of patients (108-111), though occasional mild skin reactions do occur (72). Estimates of anaphylaxis are highly variable $(90,114,115)$ but are as high as 1 in 2500-4000 patients (91, 92, 116).

One plausible mast cell-related $\mathrm{AE}$ is an injection site reaction, which occurs in up to $80 \%$ of patients given rocuronium (106). However, while intravenous rocuronium can cause a local rash (117), intravenous and intradermal rocuronium injections are associated not with itch - typical of mast cell-driven reactions - but with sharp pain and involuntary limb withdrawal $(118,119)$. One study in mice suggests that rocuronium directly activates skin C-fibers, which transmit noxious sensations like pain (119). This apparently is $\mathrm{pH}$ dependent, as neutralizing its $\mathrm{pH}$ from 3.5 to 7.4 abolished pain sensation in one human study (120). Another study reported that pain was reduced after pretreatment with the antihistamine chlorpheniramine maleate (121). However, it is quite possible that this is due to off-target activity, as the dosage given was 10 times higher than the standard amount and also was given as an intravenous bolus, which results in extremely high plasma concentrations, compared to an equivalent oral dose (122). In sum, mast cells may play a role in injection site reactions, but it seems likely that other mechanisms also contribute.

\section{Peak Plasma Concentrations and Potential MRGPRX2 Involvement}

Peak recorded plasma concentrations of rocuronium within a few minutes after rapid injection are between 6-15 micrograms/ $\mathrm{ml}$ (123-128). The calculated $\mathrm{EC}_{50}$ for MRGRPX2 activation is 261 micrograms/ml (12), so even with the caveat that plasma concentration measurements underestimate the peak when taken after infusion, it seems impossible that MRGPRX2 could be systemically activated. This readily explains why histamineassociated AEs are so rare. MRGPRX2 alleles and drug concentrations are generally not available for patients who have suffered anaphylactic episodes. One study identified expression of an allele in one patient (129), though this does not appear to increase receptor sensitivity (130).

Injection site reactions may involve MRGPRX2. Rocuronium is supplied as a $10 \mathrm{mg} / \mathrm{ml}$ injection solution, which is much higher than the reported $\mathrm{EC}_{50}$ for MRGPRX2 of 261 micrograms/ml (12), and the threshold for evoking wheal and 
flare after intradermal injection is as low as 61 micrograms $/ \mathrm{ml}$ (104). Local leakage of the drug into the area surrounding the injection site may trigger MRGPRX2-mediated mast cell activation.

\section{Morphine}

Morphine is a small molecule alkaloid which is used clinically to activate endogenous opioid receptors and relieve pain. It usually is administered orally, intravenously, or spinally as an epidural or intrathecal injection. It has been linked to allergic-type reactions for over 100 years (131).

\section{Allergic-Type Event Frequency and Mast Cell Dependence}

Pruritus is one of the most commonly-reported adverse events of any kind associated with morphine (132-134). Frequencies after epidural administration are from $8.5 \%$ to over $50 \%(135-137)$; $30 \%-100 \%$ after intrathecal administration (136-138); up to $40 \%$ after intravenous administration (139); and generally 2 $10 \%$ after oral delivery (140), though higher rates have been reported (141). Oddly, other mast cell-associated adverse events like rash and hypotension are not nearly as common, and are rarely mentioned in clinical studies that use typical drug dosing regimens (132-134). The unusually specific dominance of pruritus can be explained, at least in part, by the fact that morphine and other opioid receptor agonists can engage a mast cell-independent mechanism to trigger pruritus. The details of this mechanism have not been fully worked out, but some evidence suggests that it is mediated by a subset of opioid receptor-expressing neurons in the spinal cord that specifically mediate itch transmission (142). This may be why epidural and intrathecal administration of morphine still trigger pruritus - in fact, they have the highest incidence rates of all routes of administration - even though they bypass systemic exposure and do not activate skin mast cells at all. This also may explain why the mu opioid receptor agonist fentanyl, which does not activate mast cells (or MRGPRX2) $(13,143)$, induces pruritus with incidence rates comparable to, though somewhat less than, morphine $(144,145)$. Thus, it is not clear how much of a role mast cells play in morphine-induced pruritus after normal clinical doses.

High doses of intravenous morphine produce side effects like flushing, changes in mean arterial pressure and lowered vascular resistance $(131,146-150)$, which almost certainly are mediated by mast cells. Plasma histamine levels usually were highly elevated when measured $(146,147,150,151)$, and in two studies the cardiovascular effects were reduced by pretreatment with $\mathrm{H} 1$ and $\mathrm{H} 2$ receptor antagonists (147) or the $\mathrm{H} 1$ receptor antagonist promethazine (149). Local administration of high doses of morphine into the forearm by skin prick, intradermal injection, or infusion into a local artery produced wheals and blood vessel dilation (often reported as a "flare"), which are common markers of mast cell activation and which could be reduced by antihistamines (152-156), though it is important to note that not all of the drugs used are specific for histamine receptors. Interestingly, an in vitro study of rat aortic endothelial cells demonstrated that morphine could influence their behavior directly through opioid receptors (157), suggesting a direct effect of morphine on blood vessels. This may have a minor role in humans, as well, as skin responses could partially be blocked by the opioid receptor antagonist naloxone $(154,156)$, at least when relatively low morphine doses were used (158). Still, taken together, the studies strongly suggest that most of the vascular changes induced by high doses of morphine are due to mast cell activation.

Anaphylaxis after morphine administration is thought to be exceedingly rare, though exact calculations are lacking. It has been proposed that some deaths from overdoses may involve anaphylaxis, but this is still unclear (159).

\section{Peak Plasma and Tissue Concentrations, and Potential MRGPRX2 Involvement}

Injection site reactions after morphine administration likely are due to MRGPRX2, as formulations usually are at $10 \mathrm{mM}$ concentrations or higher and are well above the $\mathrm{EC}_{50}$ for MRGPRX2 activation of 4.5 to $7 \mu \mathrm{M}(13,18,19)$. Typical systemic doses of morphine do not achieve plasma concentrations high enough to activate MRGPRX2 to a significant extent. For instance, peak concentrations rarely exceed $14 \mathrm{nM}$ after oral dosing (160) and usually are $2 \mu \mathrm{M}$ or less, often substantially so, after intravenous administration (161-166). This lends more support to a mast cell-independent origin for morphine-induced pruritus. Higher doses and/or those delivered rapidly are much more likely to result in concentrations that exceed the $\mathrm{EC}_{50}$, though not enough recordings have been made to determine just how high these are. As described above, this is when typical events like rash and swelling are seen. Since human skin mast cells do not express opioid receptors (7), it appears likely that most true mast cell-mediated events are mediated by MRGPRX2.

\section{Fluoroquinolones}

Fluoroquinolones are a group of small molecule antibiotics which are structurally similar and are effective against Grampositive and Gram-negative bacteria (167). Popular members are ciprofloxacin, levofloxacin, and moxifloxacin. They are administered orally or intravenously. Fluoroquinolones are associated with a constellation of mild-to-moderate adverse events, including typical allergic-type effects and others that potentially have a mast cell component. Fluoroquinolones also are linked to extremely serious side effects (168-172), which, while rare, are common enough that the FDA and European Medicines Agency now discourage their use for relatively mild infections, as the risks might outweigh the benefits (173). One of these, anaphylaxis, certainly is related to mast cells; of the others, tendinopathy and tendon rupture have been linked to mast cells in other diseases.

\section{Allergic-Type Event Frequency and Mast Cell Dependence}

Fluoroquinolones have a broad side effect profile and are not as clearly linked to mast cell activation as the other drugs in this review. Surprisingly, no systematic human studies have been carried out - for instance, measuring blood histamine or tryptase levels, and pretreating patients with antihistamines - to assess 
which of the symptoms are mast cell-driven. However, many frequently reported mild-to-moderate adverse events are highly suggestive of allergic-type reactions. Rash, pruritus, injection site reactions, and hypotension have been reported in 1-4\% of patients (174-177), though occasionally frequencies are much higher (178). A relatively generic description of "allergy" occasionally is reported, with frequencies of up to $2 \%$ (179). Gastrointestinal symptoms, which could be driven by mast cells (180), occur at frequencies of up to $20 \%$ (170). With the exception of anaphylaxis, the severe side effects of fluoroquinolones - tendinitis and tendon rupture, peripheral neuropathy, central nervous system effects, increased risks of damage to the aorta, and decreases in blood sugar (171) - are not typically linked to mast cell activation. Interestingly, mast cells have been proposed to influence tendon healing after injury, perhaps weakening them $(181,182)$, so it is possible that they are involved in some way in fluoroquinolone-induced tendon inflammation. The risk of tendinopathy or tendon rupture depends dramatically on many other factors, including activity level, age, and use of corticosteroids, but fluoroquinolone use can increase this by several-fold (183). Unfortunately, the link between mast cells and any of the above symptoms remains speculative; an understanding of the full extent of mast cell involvement in fluoroquinolone-induced AEs awaits dedicated studies of the subject.

Anaphylaxis is rare but increasing in frequency; in fact, fluoroquinolones now are the second-most frequent cause of drug-induced anaphylaxis in total cases, behind beta-lactams (172). The calculated frequency of these events is as high as 1 in 20,000 administered doses, though other estimates are lower (184).

\section{Peak Plasma and Tissue Concentrations, and Potential MRGPRX2 Involvement}

Reported peak plasma concentrations for fluoroquinolones generally average 2-6 micrograms/ml after a single dose, with intravenous administration often producing higher levels than oral (174, 185-187). As seen in Table 1, only ciprofloxacin can activate MRGPRX2 at these levels. However, plasma concentrations can be much higher after multiple high dose administration - for example, plasma levels exceeding 10 micrograms $/ \mathrm{ml}$ have been recorded for ciprofloxacin (188), and over $20 \mathrm{micrograms} / \mathrm{ml}$ for levofloxacin (189-191), even several hours after intravenous infusion (189). Abnormally high plasma concentrations may also occur in patients with renal impairment (192) and poor metabolism (168). Peak concentrations may be even higher, as sampling of blood during infusions usually wasn't measured. Nonetheless, it seems likely that levels required for clinically relevant MRGPRX2 activation are only transiently achieved. This may account for the relative rarity of systemic mast cell-associated reactions, compared to other MRGPRX2 agonists like vancomycin. No measurements of drug concentrations have been made immediately after anaphylactic events that could help determine whether they might also involve MRGPRX2, nor has an analysis of allele expression been conducted.
An unusual property of many fluoroquinolones is that they accumulate in specific tissues at concentrations well above peak plasma concentrations $(187,193,194)$, and can exceed those needed to activate MRGPRX2. This is linked to the lipophilicity of the molecule (194), and some are much more likely than others to distribute unevenly. The lung, especially the epithelial lining fluid (ELF), is a site of some of the highest reported concentrations (195) - for instance, levofloxacin concentrations in the ELF have been measured at over 40 micrograms/ml (189), and two hours after a single dose of moxifloxacin, ELF concentrations reached 21 micrograms/ml (196). Limited data, mostly from experimental animal models, suggest that fluoroquinolones also accumulate in cartilage (197). This may have some significance, as fluoroquinolones are associated with arthralgia, myalgia, and joint damage in some studies (198), and mast cell mediators have been shown to weaken tendons (181). In sum, this unusual tissue distribution pattern of fluoroquinolones may result in intense mast cell activation that is both delayed and restricted to certain tissues. This would not be accompanied by the typical signs of degranulation like rash and pruritus, but a closer look at mast cell, and MRGPRX2, involvement in these delayed and long-lived side effects might be justified.

\section{DISCUSSION}

A question that is raised repeatedly in the literature is whether MRGPRX2 activation is capable of triggering anaphylaxis. This likely would require a sustained period of high plasma drug levels, and/or expression of a rare MRGRPX2 allele with greatly enhanced sensitivity to the drug or abnormally strong signaling downstream of receptor activation. Tandem testing of MRGPRX2 allele expression, drug concentrations, and IgE titers in patients with anaphylaxis would be extremely informative; unfortunately, these tests are rarely conducted and most MRGPRX2 alleles remain uncharacterized. Ultimately, an MRGPRX2 antagonist is needed to provide direct proof of MRGPRX2 involvement. Development of antagonists is in its infancy and none has made it to clinical trials yet, though several promising candidates have been identified and rapid development on this front is expected (15).

Perhaps the most surprising finding from the analysis is how common the mild-to-moderate events are. These events are not life-threatening like anaphylaxis is, and rightly should be a lesser priority for clinicians. However, they should not be neglected, either. For instance, one allergic-type response classified as moderate is a drop in mean arterial pressure of over $20 \%$ - this certainly is not a trivial effect and may have an impact on vascular stability, especially in patients who have serious cardiovascular impairment already. Comparisons with plasma drug levels suggest that MRGPRX2 drives many of these mild-tomoderate events. An MRGPRX2 antagonist is not yet available, but if one enters clinical use, it would be interesting to see if prophylactic administration before surgical procedures lowers overall perioperative patient mortality. In sum, it is clear that there is much still to be learned about MRGPRX2 and its impact on human health. 


\section{AUTHOR CONTRIBUTIONS}

The author confirms being the sole contributor of this work and has approved it for publication.

\section{REFERENCES}

1. Riedl MA, Casillas AM. Adverse Drug Reactions: Types and Treatment Options. Am Fam Physician (2003) 68:1781-90.

2. Ebo DG, Clarke RC, Mertes P-M, Platt PR, Sabato V, Sadleir PHM. Molecular Mechanisms and Pathophysiology of Perioperative Hypersensitivity and Anaphylaxis: A Narrative Review. Br J Anaesthesia (2019) 123:e38-49. doi: 10.1016/j.bja.2019.01.031

3. Cook TM, Harper NJN, Farmer L, Garcez T, Floss K, Marinho S, et al. Anaesthesia, Surgery, and Life-Threatening Allergic Reactions: Protocol and Methods of the 6th National Audit Project (NAP6) of the Royal College of Anaesthetists. Br J Anaesthesia (2018) 121:124-33. doi: 10.1016/j.bja.2018.04.001

4. Savic LC, Garvey LH. Perioperative Anaphylaxis: Diagnostic Challenges and Management. Curr Opin Anaesthesiol (2020) 33:448-53. doi: 10.1097/ ACO.0000000000000857

5. Dykewicz MS, Lam JK. Drug Hypersensitivity Reactions. Med Clin North Am (2020) 104:109-28. doi: 10.1016/j.mcna.2019.09.003

6. Galli SJ, Tsai M. Ige and Mast Cells in Allergic Disease. Nat Med (2012) 18:693-704. doi: 10.1038/nm.2755

7. Motakis E, Guhl S, Ishizu Y, Itoh M, Kawaji H, de Hoon M, et al. Redefinition of the Human Mast Cell Transcriptome by Deep-CAGE Sequencing. Blood (2014) 123:e58-67. doi: 10.1182/blood-2013-02-483792

8. Tatemoto K, Nozaki Y, Tsuda R, Konno S, Tomura K, Furuno M, et al. Immunoglobulin E-Independent Activation of Mast Cell Is Mediated by Mrg Receptors. Biochem Biophys Res Commun (2006) 349:1322-8. doi: 10.1016/j.bbrc.2006.08.177

9. Armstrong JF, Faccenda E, Harding SD, Pawson AJ, Southan C, Sharman JL, et al. The IUPHAR/BPS Guide to PHARMACOLOGY in 2020: Extending Immunopharmacology Content and Introducing the IUPHAR/MMV Guide to MALARIA PHARMACOLOGY. Nucleic Acids Res (2019) 48:D1006-21. doi: $10.1093 /$ nar/gkz951

10. Robas N, Mead E, Fidock M. MrgX2 Is a High Potency Cortistatin Receptor Expressed in Dorsal Root Ganglion. J Biol Chem (2003) 278:44400-4. doi: 10.1074/jbc.M302456200

11. Kamohara M, Matsuo A, Takasaki J, Kohda M, Matsumoto M, Matsumoto S, et al. Identification of MrgX2 as a Human G-Protein-Coupled Receptor for Proadrenomedullin N-Terminal Peptides. Biochem Biophys Res Commun (2005) 330:1146-52. doi: 10.1016/j.bbrc.2005.03.088

12. McNeil BD, Pundir P, Meeker S, Han L, Undem BJ, Kulka M, et al. Identification of a Mast-Cell-Specific Receptor Crucial for Pseudo-Allergic Drug Reactions. Nature (2015) 519:237-41. doi: 10.1038/nature14022

13. Lansu K, Karpiak J, Liu J, Huang XP, McCorvy JD, Kroeze WK, et al. In Silico Design of Novel Probes for the Atypical Opioid Receptor MRGPRX2. Nat Chem Biol (2017) 13:529-36. doi: 10.1038/nchembio.2334

14. Grimes J, Desai S, Charter NW, Lodge J, Moita Santos R, Isidro-Llobet A, et al. MrgX2 is a Promiscuous Receptor for Basic Peptides Causing Mast Cell Pseudo-Allergic and Anaphylactoid Reactions. Pharmacol Res Perspect (2019) 7:e00547. doi: 10.1002/prp2.547

15. McNeil BD. Minireview: Mas-Related G Protein-Coupled Receptor X2 Activation by Therapeutic Drugs. Neurosci Lett (2021) 751:135746. doi: 10.1016/j.neulet.2021.135746

16. Che D, Wang J, Ding Y, Liu R, Cao J, Zhang Y, et al. Mivacurium Induce Mast Cell Activation and Pseudo-Allergic Reactions via MAS-Related G Protein Coupled Receptor-X2. Cell Immunol (2018) 332:121-8. doi: 10.1016/ j.cellimm.2018.08.005

17. Che D, Rui L, Cao J, Wang J, Zhang Y, Ding Y, et al. Cisatracurium Induces Mast Cell Activation and Pseudo-Allergic Reactions via MRGPRX2. Int Immunopharmacol (2018) 62:244-50. doi: 10.1016/j.intimp.2018.07.020

18. Zhang T, Liu R, Che D, Pundir P, Wang N, Han S, et al. A Mast Cell-Specific Receptor Is Critical for Granuloma Induced by Intrathecal Morphine Infusion. J Immunol (2019) 203:1701-14. doi: 10.4049/jimmunol.1801423

\section{FUNDING}

This article was written with the support of the Ernest S. Bazley Trust.

19. Akuzawa N, Obinata H, Izumi T, Takeda S. Morphine Is an Exogenous Ligand for MrgX2, a G Protein-Coupled Receptor for Cortistatin. J Cell Anim Biol (2009) 3:216-21. doi: 10.5897/JCAB.9000111

20. Gaudenzio N, Sibilano R, Marichal T, Starkl P, Reber LL, Cenac N, et al. Different Activation Signals Induce Distinct Mast Cell Degranulation Strategies. J Clin Invest (2016) 126:3981-98. doi: 10.1172/JCI85538

21. Porebski G, Kwiecien K, Pawica M, Kwitniewski M. Mas-Related G ProteinCoupled Receptor-X2 (MRGPRX2) in Drug Hypersensitivity Reactions. Front Immunol (2018) 9. doi: 10.3389/fimmu.2018.03027

22. Munk C, Isberg V, Mordalski S, Harpsøe K, Rataj K, Hauser AS, et al. Gpcrdb: The G Protein-Coupled Receptor Database - An Introduction. $\mathrm{Br} J$ Pharmacol (2016) 173:2195-207. doi: 10.1111/bph.13509

23. Alkanfari I, Gupta K, Jahan T, Ali H. Naturally Occurring Missense MRGPRX2 Variants Display Loss of Function Phenotype for Mast Cell Degranulation in Response to Substance P, Hemokinin-1, Human $\beta$-Defensin-3, and Icatibant. J Immunol (2018) 201:343-9. doi: 10.4049/jimmunol.1701793

24. Chompunud Na Ayudhya C, Roy S, Alkanfari I, Ganguly A, Ali H. Identification of Gain and Loss of Function Missense Variants in MRGPRX2's Transmembrane and Intracellular Domains for Mast Cell Activation by Substance P. Int J Mol Sci (2019) 20:5247. doi: 10.3390/ ijms20215247

25. Varricchi G, Pecoraro A, Loffredo S, Poto R, Rivellese F, Genovese A, et al. Heterogeneity of Human Mast Cells With Respect to MRGPRX2 Receptor Expression and Function. Front Cell Neurosci (2019) 13. doi: 10.3389/ fncel.2019.00299

26. Shtessel M, Limjunyawong N, Oliver ET, Chichester K, Gao L, Dong X, et al. MRGPRX2 Activation Causes Increased Skin Reactivity in Patients With Chronic Spontaneous Urticaria. J Invest Dermatol (2021) 141:678-81.e672. doi: 10.1016/j.jid.2020.06.030

27. Ansotegui IJ, Melioli G, Canonica GW, Caraballo L, Villa E, Ebisawa M, et al. Ige Allergy Diagnostics and Other Relevant Tests in Allergy, a World Allergy Organization Position Paper. World Allergy Organ J (2020) 13:100080. doi: 10.1016/j.waojou.2019.100080

28. Ariza A, Mayorga C, Bogas G, Barrionuevo E, Torres MJ, Doña I, et al. Advances and Novel Developments in Drug Hypersensitivity Diagnosis. Allergy (2020) 75:3112-23. doi: 10.1111/all.14603

29. Decuyper II, Mangodt EA, Van Gasse AL, Claesen K, Uyttebroek A, Faber M, et al. In Vitro Diagnosis of Immediate Drug Hypersensitivity Anno 2017: Potentials and Limitations. Drugs R\&D (2017) 17:265-78. doi: 10.1007/ s40268-017-0176-x

30. Brockow K, Garvey LH, Aberer W, Atanaskovic-Markovic M, Barbaud A, Bilo MB, et al. Skin Test Concentrations for Systemically Administered Drugs - An ENDA/EAACI Drug Allergy Interest Group Position Paper. Allergy (2013) 68:702-12. doi: 10.1111/all.12142

31. Van Gasse AL, Elst J, Bridts CH, Mertens C, Faber M, Hagendorens MM, et al. Rocuronium Hypersensitivity: Does Off-Target Occupation of the MRGPRX2 Receptor Play a Role? J Allergy Clin Immunol Pract (2019) 7:998-1003. doi: 10.1016/j.jaip.2018.09.034

32. Liu C, Bayer A, Cosgrove SE, Daum RS, Fridkin SK, Gorwitz RJ, et al. Clinical Practice Guidelines by the Infectious Diseases Society of America for the Treatment of Methicillin-Resistant Staphylococcus Aureus Infections in Adults and Children: Executive Summary. Clin Infect Dis (2011) 52:285-92. doi: $10.1093 / \mathrm{cid} / \mathrm{cir} 034$

33. De Luca JF, Holmes NE, Trubiano JA. Adverse Reactions to Vancomycin and Cross-Reactivity With Other Antibiotics. Curr Opin Allergy Clin Immunol (2020) 20:352-61. doi: 10.1097/ACI.0000000000000665

34. Myers AL, Gaedigk A, Dai H, James LP, Jones BL, Neville KA. Defining Risk Factors for Red Man Syndrome in Children and Adults. Pediatr Infect Dis J (2012) 31:464-8. doi: 10.1097/INF.0b013e31824e10d7

35. Huang V, Clayton NA, Welker KH. Glycopeptide Hypersensitivity and Adverse Reactions. Pharmacy (2020) 8:70. doi: 10.3390/pharmacy8020070 
36. Polk RE. Anaphylactoid Reactions to Glycopeptide Antibiotics. J Antimicrobial Chemotherapy (1991) 27:17-29. doi: 10.1093/jac/ 27.suppl_B.17

37. Levy JH, Kettlekamp N, Goertz P, Hermens J, Hirshman CA. Histamine Release by Vancomycin: A Mechanism for Hypotension in Man. Anesthesiology (1987) 67:122-5. doi: 10.1097/00000542-198707000-00026

38. Polk RE, Healy DP, Schwartz LB, Rock DT, Garson ML, Roller K. Vancomycin and the Red-Man Syndrome: Pharmacodynamics of Histamine Release. J Infect Dis (1988) 157:502-7. doi: 10.1093/infdis/ 157.3.502

39. Healy DP, Sahai JV, Fuller SH, Polk RE. Vancomycin-Induced Histamine Release and "Red Man Syndrome": Comparison of 1- and 2-Hour Infusions. Antimicrobial Agents Chemotherapy (1990) 34:550-4. doi: 10.1128/ AAC. 34.4 .550

40. Sahai J, Healy DP, Shelton MJ, Miller JS, Ruberg SJ, Polk R. Comparison of Vancomycin- and Teicoplanin-Induced Histamine Release and "Red Man Syndrome". Antimicrob Agents Chemother (1990) 34:765-9. doi: 10.1128/ AAC. 34.5 .765

41. Renz C, Lynch J, Thurn J, Moss J. Histamine Release During Rapid Vancomycin Administration. Inflammation Res (1998) 47:69-70. doi: $10.1007 / \mathrm{s} 000110050279$

42. Sahai J, Healy DP, Garris R, Berry A, Polk RE. Influence of Antihistamine Pretreatment on Vancomycin-Induced Red-Man Syndrome. J Infect Dis (1989) 160:876-81. doi: 10.1093/infdis/160.5.876

43. Wallace MR, Mascola JR, Oldfield EC. Red Man Syndrome: Incidence, Etiology, and Prophylaxis. J Infect Dis (1991) 164:1180-5. doi: 10.1093/ infdis/164.6.1180

44. Renz CL, Thurn JD, Finn HA, Lynch JP, Moss J. Oral Antihistamines Reduce the Side Effects From Rapid Vancomycin Infusion. Anesth Analg (1998) 87:681-5. doi: 10.1213/00000539-199809000-00036

45. Renz CL, Thurn JD, Finn HA, Lynch JP, Moss J. Antihistamine Prophylaxis Permits Rapid Vancomycin Infusion. Crit Care Med (1999) 27:1732-7. doi: 10.1097/00003246-199909000-00006

46. Renz CL, Laroche D, Thurn JD, Finn HA, Lynch JP, Thisted R, et al. Tryptase Levels Are Not Increased During Vancomycin-Induced Anaphylactoid Reactions. Anesthesiology (1998) 89:620-5. doi: 10.1097/ 00000542-199809000-00010

47. Svetitsky S, Leibovici L, Paul M. Comparative Efficacy and Safety of Vancomycin Versus Teicoplanin: Systematic Review and Meta-Analysis. Antimicrob Agents Chemother (2009) 53:4069-79. doi: 10.1128/AAC.00341-09

48. Korman TM, Turnidge JD, Grayson ML. Risk Factors for Adverse Cutaneous Reactions Associated With Intravenous Vancomycin. J Antimicrobial Chemotherapy (1997) 39:371-81. doi: 10.1093/ oxfordjournals.jac.a020861

49. Rybak MJ, Bailey EM, Warbasse LH. Absence of "Red Man Syndrome" in Patients Being Treated With Vancomycin or High-Dose Teicoplanin. Antimicrob Agents Chemother (1992) 36:1204-7. doi: 10.1128/AAC.36.6.1204

50. O'Sullivan TL, Ruffing MJ, Lamp KC, Warbasse LH, Rybak MJ. Prospective Evaluation of Red Man Syndrome in Patients Receiving Vancomycin. J Infect Dis (1993) 168:773-6. doi: 10.1093/infdis/168.3.773

51. Marinho DS, Huf G, Ferreira BL, Castro H, Rodrigues CR, Sousa VPD, et al. The Study of Vancomycin Use and Its Adverse Reactions Associated to Patients of a Brazilian University Hospital. BMC Res Notes (2011) 4:236. doi: 10.1186/1756-0500-4-236

52. Downs NJ. Mild Nephrotoxicity Associated With Vancomycin Use. Arch Internal Med (1989) 149:1777. doi: 10.1001/archinte.1989.00390080053013

53. Rubin M, Hathorn JW, Marshall D, Gress J, Steinberg SM, Pizzo PA. GramPositive Infections and the Use of Vancomycin in 550 Episodes of Fever and Neutropenia. Ann Intern Med (1988) 108:30-5. doi: 10.7326/0003-4819108-1-30

54. Alvarez-Arango S, Yerneni S, Tang O, Zhou L, Mancini CM, Blackley SV, et al. Vancomycin Hypersensitivity Reactions Documented in Electronic Health Records. J Allergy Clin Immunol Pract (2021) 9:906-12. doi: 10.1016/ j.jaip.2020.09.027

55. Healy DP, Polk RE, Garson ML, Rock DT, Comstock TJ. Comparison of Steady-State Pharmacokinetics of Two Dosage Regimens of Vancomycin in Normal Volunteers. Antimicrobial Agents Chemotherapy (1987) 31:393-7. doi: 10.1128/AAC.31.3.393
56. Polk RE, Israel D, Wang J, Venitz J, Miller J, Stotka J. Vancomycin Skin Tests and Prediction of "Red Man Syndrome" in Healthy Volunteers. Antimicrobial Agents Chemotherapy (1993) 37:2139-43. doi: 10.1128/ AAC.37.10.2139

57. Boeckh M, Lode H, Borner K, Hoffken G, Wagner J, Koeppe P. Pharmacokinetics and Serum Bactericidal Activity of Vancomycin Alone and in Combination With Ceftazidime in Healthy Volunteers. Antimicrobial Agents Chemotherapy (1988) 32:92-5. doi: 10.1128/AAC.32.1.92

58. Odio C. Adverse Reactions to Vancomycin Used as Prophylaxis for CSF Shunt Procedures. Arch Pediatr Adolesc Med (1984) 138:17. doi: 10.1001/ archpedi.1984.02140390009004

59. Johnzon C-F, Rönnberg E, Pejler G. The Role of Mast Cells in Bacterial Infection. Am J Pathol (2016) 186:4-14. doi: 10.1016/j.ajpath.2015.06.024

60. Lee C. Structure, Conformation, and Action of Neuromuscular Blocking Drugs †. Br J Anaesthesia (2001) 87:755-69. doi: 10.1093/bja/87.5.755

61. Claudius C, Garvey LH, Viby-Mogensen J. The Undesirable Effects of Neuromuscular Blocking Drugs. Anaesthesia (2009) 64:10-21. doi: 10.1111/j.1365-2044.2008.05866.x

62. Bryson HM, Faulds D. Cisatracurium Besilate. Drugs (1997) 53:848-66. doi: 10.2165/00003495-199753050-00012

63. Konstadt SN, Reich DL, Stanley TE, Deperio M, Chuey C, Schwartzbach C, et al. A Two-Center Comparison of the Cardiovascular Effects of Cisatracurium (Nimbex Trademmark) and Vecuronium in Patients With Coronary Artery Disease. Anesthesia Analgesia (1995) 81:1010-4. doi: 10.1213/00000539-199511000-00020

64. Hughes R, Chapple DJ. The Pharmacology of Atracurium: A New Competitive Neuromuscular Blocking Agent. Br J Anaesthesia (1981) 53:31-44. doi: 10.1093/bja/53.1.31

65. Scott RP, Savarese JJ, Basta SJ, Embree P, Ali HH, Sunder N, et al. Clinical Pharmacology of Atracurium Given in High Dose. Br J Anaesth (1986) 58:834-8. doi: $10.1093 / \mathrm{bja} / 58.8 .834$

66. Scott RP, Savarese JJ, Basta SJ, Sunder N, Ali HH, Gargarian M, et al. Atracurium: Clinical Strategies for Preventing Histamine Release and Attenuating the Haemodynamic Response. Br J Anaesth (1985) 57:550-3. doi: $10.1093 / \mathrm{bja} / 57.6 .550$

67. Hosking MP, Lennon RL, Gronert GA. Combined H1 and H2 Receptor Blockade Attenuates the Cardiovascular Effects of High-Dose Atracurium for Rapid Sequence Endotracheal Intubation. Anesth Analg (1988) 67:108992. doi: 10.1213/00000539-198867110-00012

68. Adt M, Baumert JH, Reimann HJ. The Role of Histamine in the Cardiovascular Effects of Atracurium. Br J Anaesthesia (1992) 68:155-60. doi: 10.1093/bja/68.2.155

69. Doenicke A, Moss J, Lorenz W, Hoernecke R, Gottardis M. Are Hypotension and Rash After Atracurium Really Caused by Histamine Release? Anesthesia Analgesia (1994) 78:967???972. doi: 10.1213/00000539-199405000-00023

70. Savarese JJ, Ali HH, Basta SJ, Scott RP, Embree PB, Wastila WB, et al. The Cardiovascular Effects of Mivacurium Chloride (BW B1090U) in Patients Receiving Nitrous Oxide-Opiate-Barbiturate Anesthesia. Anesthesiology (1989) 70:386-94. doi: 10.1097/00000542-198903000-00003

71. Shorten GD, Crawford MW, St Louis P. The Neuromuscular Effects of Mivacurium Chloride During Propofol Anesthesia in Children. Anesth Analg (1996) 82:1170-5. doi: 10.1213/00000539-199606000-00012

72. Xiang Z, Yan-Liang Q, Xiao-Yang S, Yan-Hui Z, Min C, Guo-Shen G, et al. Effects of Promethazine or Dexamethasone Pretreatment on MivacuriumInduced Histamine Release in Children. Pediatr Anesthesia (2014) 24:322-6. doi: $10.1111 /$ pan. 12305

73. Naguib M, Samarkandi AH, Bakhamees HS, Magboul MA, El-Bakry AK. Histamine-Release Haemodynamic Changes Produced by Rocuronium, Vecuronium, Mivacurium, Atracurium and Tubocurarine. $\mathrm{Br}$ J Anaesthesia (1995) 75:588-92. doi: 10.1093/bja/75.5.588

74. Brandom BW, Meretoja OA, Simhi E, Taivainen T, Wolfe SR, Woelfel SK, et al. Age Related Variability in the Effects of Mivacurium in Paediatric Surgical Patients. Can J Anaesthesia (1998) 45:410-6. doi: 10.1007/ BF03012575

75. Miguel R, Witkowski T, Nagashima H, Fragen R, Bartkowski R, Foldes FF, et al. Evaluation of Neuromuscular and Cardiovascular Effects of Two Doses of Rapacuronium (ORG 9487) Versus Mivacurium and Succinylcholine. Anesthesiology (1999) 91:1648-54. doi: 10.1097/00000542-199912000-00016 
76. Sarner JB, Brandom BW, Woelfel SK, Dong M-L, Horn MC, Cook RD, et al. Clinical Pharmacology of Mivacurium Chloride (BW B1090U) in Children During Nitrous Oxide-Halothane and Nitrous Oxide-Narcotic Anesthesia. Anesthesia Analgesia (1989) 68:116-21. doi: 10.1213/00000539-19890200000009

77. Ali HH, Lien CA, Witkowski T, Brull SJ, Stout RG, Bartkowski R, et al. Efficacy and Safety of Divided Dose Administration of Mivacurium for a 90Second Tracheal Intubation. J Clin Anesthesia (1996) 8:276-81. doi: 10.1016/ 0952-8180(96)85617-0

78. Doenicke A, Moss J, Lorenz W, Mayer M, Rau J, Jedrzejewski A, et al. Effect of Oral Antihistamine Premedication on Mivacurium-Induced Histamine Release and Side Effects. Br J Anaesthesia (1996) 77:421-3. doi: 10.1093/bja/ 77.3.421

79. Loan PB, Elliott P, Mirakhur RK, Bunting HF, Bhanumurthy S, McMurray TJ. Comparison of the Haemodynamic Effects of Mivacurium and Atracurium During Fentanyl Anaesthesia. Br J Anaesthesia (1995) 74:3302. doi: $10.1093 / \mathrm{bja} / 74.3 .330$

80. Plaud B, Marty J, Debaene B, Meistelman C, Pellissier D, LePage JY, et al. The Cardiovascular Effects of Mivacurium in Hypertensive Patients. Anesth Analg (2002) 95:379-84. doi: 10.1213/00000539-200208000-00025

81. Miloudi Y, El Harrar N, Bensaid A, Hussein MA. Les Réactions Cutanées Consécutives À L'induction Anesthésique Au Mivacurium. Annales Françaises d'Anesthésie Réanimation (2007) 26:717. doi: 10.1016/ j.annfar.2007.04.002

82. Stoops CM, Curtis CA, Kovach DA, McCammon RL, Stoelting RK, Warren TM, et al. Hemodynamic Effects of Mivacurium Chloride Administered to Patients During Oxygen-Sufentanil Anesthesia for Coronary Artery Bypass Grafting or Valve Replacement. Anesth Analg (1989) 68:333-9. doi: 10.1213/ 00000539-198903000-00028

83. Hodgson R, Harvey P, Burrows R. Mivacurium Compared With Three Different Doses of Suxamethonium for Nasotracheal Intubation. Anaesthesia Intensive Care (1998) 26:521-5. doi: 10.1177/0310057X 9802600508

84. Zeng R, Liu X, Zhang J, Yin N, Fei J, Zhong S, et al. The Efficacy and Safety of Mivacurium in Pediatric Patients. BMC Anesthesiology (2017) 17:58-65. doi: 10.1186/s12871-017-0350-2

85. Reich DL, Mulier J, Viby-Mogensen J, Konstadt SN, Van Aken HK, Jensen FS, et al. Comparison of the Cardiovascular Effects of Cisatracurium and Vecuronium in Patients With Coronary Artery Disease. Can J Anaesthesia (1998) 45:794-7. doi: 10.1007/BF03012152

86. Lepage JY, Malinovsky JM, Malinge M, Lechevalier T, Dupuch C, Cozian A, et al. Pharmacodynamic Dose-Response and Safety Study of Cisatracurium (51W89) in Adult Surgical Patients During N2O-O2-Opioid Anesthesia. Anesth Analg (1996) 83:823-9. doi: 10.1097/00000539-199610000-00030

87. Doenicke A, Soukup J, Hoernecke R, Moss J. The Lack of Histamine Release With Cisatracurium: A Double-Blind Comparison With Vecuronium. Anesth Analg (1997) 84:623-8. doi: 10.1213/00000539-199703000-00030

88. Doenicke AW, Czeslick E, Moss J, Hoernecke R, time O. Endotracheal Intubating Conditions, and Plasma Histamine After Cisatracurium and Vecuronium Administration. Anesth Analg (1998) 87:434-8. doi: 10.1213/ 00000539-199808000-00038

89. Lien CA, Belmont MR, Abalos A, Eppich L, Quessy S, Abou-Donia MM, et al. The Cardiovascular Effects and Histamine-Releasing Properties of 51W89 in Patients Receiving Nitrous Oxide/Opioid/Barbiturate Anesthesia. Anesthesiology (1995) 82:1131-8. doi: 10.1097/00000542-199505000-00007

90. Harper NJN, Cook TM, Garcez T, Farmer L, Floss K, Marinho S, et al. Anaesthesia, Surgery, and Life-Threatening Allergic Reactions: Epidemiology and Clinical Features of Perioperative Anaphylaxis in the 6th National Audit Project (NAP6). Br J Anaesthesia (2018) 121:159-71. doi: 10.1016/j.bja.2018.04.014

91. Reddy JI, Cooke PJ, Van Schalkwyk JM, Hannam JA, Fitzharris P, Mitchell SJ. Anaphylaxis is More Common With Rocuronium and Succinylcholine Than With Atracurium. Anesthesiology (2015) 122:39-45. doi: 10.1097/ ALN.0000000000000512

92. Petitpain N, Argoullon L, Masmoudi K, Fedrizzi S, Cottin J, Latarche C, et al. Neuromuscular Blocking Agents Induced Anaphylaxis: Results and Trends of a French Pharmacovigilance Survey From 2000 to 2012. Allergy (2018) 73:2224-33. doi: 10.1111/all.13456
93. Sadleir PHM, Clarke RC, Bunning DL, Platt PR. Anaphylaxis to Neuromuscular Blocking Drugs: Incidence and Cross-Reactivity in Western Australia From 2002 to 2011. Br J Anaesthesia (2013) 110:981-7. doi: 10.1093/bja/aes506

94. Kent AP, Parker CJR, Hunter JM. Pharmacokinetics of Atracurium and Laudanosine in the Elderly. Br J Anaesthesia (1989) 63:661-6. doi: 10.1093/ $\mathrm{bja} / 63.6 .661$

95. Ward S, Neill EAM, Weatherley BC, Corall IM. Pharmacokinetics of Atracurium Besylate in Healthy Patients (After a Single I.V. Bolus Dose). Br J Anaesthesia (1983) 55:113-8. doi: 10.1093/bja/55.2.113

96. Levy JH, Adelson D, Walker B. Wheal and Flare Responses to Muscl Relaxants in Humans. Agents Actions (1991) 34:302-8. doi: 10.1007/ BF01988720

97. Østergaard D, Viby-Mogensen J, Rasmussen SN, Gätke MR, Varin F. Pharmacokinetics and Pharmacodynamics of Mivacurium in Patients Phenotypically Homozygous for the Atypical Plasma Cholinesterase Variant. Anesthesiology (2005) 102:1124-32. doi: 10.1097/00000542-200506000-00011

98. Lacroix M, Donati F, Varin F. Pharmacokinetics of Mivacurium Isomers and Their Metabolites in Healthy Volunteers After Intravenous Bolus Administration. Anesthesiology (1997) 86:322-30. doi: 10.1097/00000542199702000-00008

99. Cook DR, Freeman JA, Lai AA, Kang Y, Stiller RL, Aggarwal S, et al. Pharmacokinetics of Mivacurium N Normal Patients and in Those With Hepatic or Renal Failure. Br J Anaesthesia (1992) 69:580-5. doi: 10.1093/bja/ 69.6.580

100. Lien CA, Schmith VD, Embree PB, Belmont MR, Wargin WA, Savarese JJ. The Phamtacokinetics and Pharmacodynamics of the Stereoisomers of Mivacurium in Patients Receiving Nitrous Oxide/Opioid/Barbiturate Anesthesia. Anesthesiology (1994) 80:1296-302. doi: 10.1097/00000542199406000-00017

101. Østergaard D, Gätke MR, Berg H, Rasmussen SN, Viby-Mogensen J. The Pharmacodynamics and Pharmacokinetics of Mivacurium in Children. Acta Anaesthesiologica Scandinavica (2002) 46:512-8. doi: 10.1034/j.13996576.2002.460507.x

102. De Wolf AM, Freeman JA, Scott VL, Tullock W, Smith DA, Kisor DF, et al. Pharmacokinetics and Pharmacodynamics of Cisatracurium in Patients With End-Stage Liver Disease Undergoing Liver Transplantation. $\mathrm{Br} J$ Anaesthesia (1996) 76:624-8. doi: 10.1093/bja/76.5.624

103. Kisor DF, Schmith VD, Wargin WA, Lien CA, Ornstein E, Cook DR. Importance of the Organ-Independent Elimination of Cisatracurium. Anesth Analg (1996) 83:1065-71. doi: 10.1213/00000539-199611000-00029

104. Levy JH, Gottge M, Szlam F, Zaffer R, McCall C. Weal and Flare Responses to Intradermal Rocuronium and Cisatracurium in Humans. $\mathrm{Br} J$ Anaesthesia (2000) 85:844-9. doi: 10.1093/bja/85.6.844

105. Berg CM, Heier T, Wilhelmsen V, Florvaag E. Rocuronium and Cisatracurium-Positive Skin Tests in non-Allergic Volunteers: Determination of Drug Concentration Thresholds Using a Dilution Titration Technique*. Acta Anaesthesiologica Scandinavica (2003) 47:57682. doi: 10.1034/j.1399-6576.2003.00093.x

106. Sparr HJ, Beaufort TM, Fuchs-Buder T. Newer Neuromuscular Blocking Agents. Drugs (2001) 61:919-42. doi: 10.2165/00003495-200161070-00003

107. Sorgenfrei IF, Norrild K, Larsen PB, Stensballe J, Østergaard D, Prins ME, et al. Reversal of Rocuronium-Induced Neuromuscular Block by the Selective Relaxant Binding Agent Sugammadex. Anesthesiology (2006) 104:667-74. doi: 10.1097/00000542-200604000-00009

108. Booij LHDJ, Knape HTA. The Neuromuscular Blocking Effect of Org 9426. Anaesthesia (1991) 46:341-3. doi: 10.1111/j.1365-2044.1991.tb09539.x

109. Hudson ME, Rothfield KP, Tullock WC, Firestone LL. Haemodynamic Effects of Rocuronium Bromide in Adult Cardiac Surgical Patients. Can J Anaesthesia (1998) 45:139-43. doi: 10.1007/BF03013252

110. Schramm WM, Strasser K, Bartunek A, Gilly H, Spiss CK. Effects of Rocuronium and Vecuronium on Intracranial Pressure, Mean Arterial Pressure and Heart Rate in Neurosurgical Patients. Br J Anaesthesia (1996) 77:607-11. doi: 10.1093/bja/77.5.607

111. McCoy EP, Maddineni VR, Elliott P, Mirakhur RK, Carson IW, Cooper RA. Haemodynamic Effects of Rocuronium During Fentanyl Anaesthesia: Comparison With Vecuronium. Can J Anaesthesia (1993) 40:703-8. doi: 10.1007/BF03009764 
112. Murray MJ, Deblock H, Erstad B, Gray A, Jacobi J, Jordan C, et al. Clinical Practice Guidelines for Sustained Neuromuscular Blockade in the Adult Critically Ill Patient. Crit Care Med (2016) 44:2079-103. doi: 10.1097/ CCM.0000000000002027

113. Levy JH, Davis GK, Duggan J, Szlam F. Determination of the Hemodynamics and Histamine Release of Rocuronium (Org 9426) When Administered in Increased Doses Under N2O/O2-Sufentanil Anesthesia. Anesth Analg (1994) 78:318-21. doi: 10.1213/00000539-199402000-00020

114. Takazawa T, Mitsuhata H, Mertes PM. Sugammadex and RocuroniumInduced Anaphylaxis. J Anesthesia (2016) 30:290-7. doi: 10.1007/s00540015-2105-x

115. Hepner DL, Castells MC. Anaphylaxis During the Perioperative Period. Anesthesia Analgesia (2003) 97:1381-95. doi: 10.1213/01.ANE.0000082993.84883.7D

116. Neal SM, Manthri PR, Gadiyar V, Wildsmith JA. Histaminoid Reactions Associated With Rocuronium. Br J Anaesthesia (2000) 84:108-11. doi: 10.1093/oxfordjournals.bja.a013365

117. Erbabacan E, Koksal GM, Tutuncu CA, Ekici B, Tunali Y, Kaya G, et al. Comparison of the Effect of Different Concentrations of Rocuronium on Injection Pain and Haemodynamics Using Isolated Forearm Technique. Turkish J Anesthesia Reanimation (2013) 41:162-6. doi: 10.5152/TJAR.2013.35

118. Borgeat A, Kwiatkowski D. Spontaneous Movements Associated With Rocuronium: Is Pain on Injection the Cause? Br J Anaesth (1997) 79:3823. doi: $10.1093 / \mathrm{bja} / 79.3 .382$

119. Blunk JA, Seifert F, Schmelz M, Reeh PW, Koppert W. Injection Pain of Rocuronium and Vecuronium is Evoked by Direct Activation of Nociceptive Nerve Endings. Eur J Anaesthesiol (2003) 20:245-53. doi: 10.1097/00003643200303000-00011

120. Han DW, Koo BN, Choi SH, Lee JS, Shin YS, Sharma M, et al. Neutralized Rocuronium (Ph 7.4) Before Administration Prevents Injection Pain in Awake Patients: A Randomized Prospective Trial. J Clin Anesthesia (2007) 19:418-23. doi: 10.1016/j.jclinane.2007.02.012

121. Lee HJ, Han SJ, Kim H, Lee IO, Kong MH, Kim NS, et al. Antihistamine Pretreatment to Reduce Incidence of Withdrawal Movement After Rocuronium Injection. J Korean Med Sci (2009) 24:879. doi: 10.3346/ jkms.2009.24.5.879

122. Huang SM, Athanikar NK, Sridhar K, Huang YC, Chiou WL. Pharmacokinetics of Chlorpheniramine After Intravenous and Oral Administration in Normal Adults. Eur J Clin Pharmacol (1982) 22:35965. doi: $10.1007 / \mathrm{BF} 00548406$

123. Wierda JMKH, Kleef UW, Lambalk LM, Kloppenburg WD, Agoston S. The Pharmacodynamics and Pharmacokinetics of Org 9426, A New NonDepolarizing Neuromuscular Blocking Agent, in Patients Anaesthetized With Nitrous Oxide, Halothane and Fentanyl. Can J Anaesthesia (1991) 38:430-5. doi: 10.1007/BF03007578

124. Magorian T, Wood P, Caldwell J, Fisher D, Segredo V, Szenohradszky J, et al. The Pharmacokinetics and Neuromuscular Effects of Rocuronium Bromide in Patients With Liver Disease. Anesthesia Analgesia (1995) 80:754-9. doi: 10.1213/00000539-199504000-00018

125. Cooper RA, Maddineni VR, Mirakhur RK, Wierda JM, Brady M, Fitzpatrick KT. Time Course of Neuromuscular Effects and Pharmacokinetics of Rocuronium Bromide (Org 9426) During Isoflurane Anaesthesia in Patients With and Without Renal Failure. Br J Anaesth (1993) 71:222-6. doi: $10.1093 / \mathrm{bja} / 71.2 .222$

126. Van Miert MM, Eastwood NB, Boyd AH, Parker CJR, Hunter JM. The Pharmacokinetics and Pharmacodynamics of Rocuronium in Patients With Hepatic Cirrhosis. Br J Clin Pharmacol (1997) 44:139-44. doi: 10.1046/ j.1365-2125.1997.00653.x

127. Szenohradszky J, Fisher DM, Segredo V, Caldwell JE, Bragg P, Sharma ML, et al. Pharmacokinetics of Rocuronium Bromide (ORG 9426) in Patients With Normal Renal Function or Patients Undergoing Cadaver Renal Transplantation. Anesthesiology (1992) 77:899-904. doi: 10.1097/ 00000542-199211000-00010

128. Servin FS, Lavaut E, Kleef U, Desmonts JM. Repeated Doses of Rocuronium Bromide Administered to Cirrhotic and Control Patients Receiving Isoflurane. Anesthesiology (1996) 84:1092-100. doi: 10.1097/00000542199605000-00011

129. Suzuki Y, Liu S, Kadoya F, Takasaki Y, Yorozuya T, Mogi M. Association Between Mutated Mas-Related G Protein-Coupled Receptor-X2 and
Rocuronium-Induced Intraoperative Anaphylaxis. Br J Anaesth (2020) 125: e446-8. doi: 10.1016/j.bja.2020.05.046

130. Chompunud Na Ayudhya C, Amponnawarat A, Roy S, Oskeritzian CA, Ali H. MRGPRX2 Activation by Rocuronium: Insights From Studies With Human Skin Mast Cells and Missense Variants. Cells (2021) 10:156. doi: 10.3390/cells10010156

131. Baldo BA, Pham NH. Histamine-Releasing and Allergenic Properties of Opioid Analgesic Drugs: Resolving the Two. Anaesthesia Intensive Care (2012) 40:216-35. doi: 10.1177/0310057X1204000204

132. Swegle JM, Logemann C. Management of Common Opioid-Induced Adverse Effects. Am Fam Physician (2006) 74:1347-54.

133. Donnelly S, Davis MP, Walsh D, Naughton M. Morphine in Cancer Pain Management: A Practical Guide. Supportive Care Cancer (2002) 10:13-35. doi: $10.1007 /$ s005200100274

134. Aronson JK. Meyler's Side Effects of Drugs. Sixteenth Edition. JK Aronson, editor. Oxford: Elsevier (2016). p. 1111-27.

135. Du B-X, Song Z-M, Wang K, Zhang H, Xu F-Y, Zou Z, et al. Butorphanol Prevents Morphine-Induced Pruritus Without Increasing Pain and Other Side Effects: A Systematic Review of Randomized Controlled Trials. Can J Anesthesia/Journal canadien d'anesthésie (2013) 60:907-17. doi: 10.1007/ s12630-013-9989-4

136. Ballantyne JC, Loach AB, Carr DB. Itching After Epidural and Spinal Opiates. Pain (1988) 33:149-60. doi: 10.1016/0304-3959(88)90085-1

137. Kjellberg F, Tramèr MR. Pharmacological Control of Opioid-Induced Pruritus: A Quantitative Systematic Review of Randomized Trials. Eur J Anaesthesiol (2001) 18:346-57. doi: 10.1097/00003643-200106000-00002

138. Kumar K, Singh SI. Neuraxial Opioid-Induced Pruritus: An Update. J Anaesthesiol Clin Pharmacol (2013) 29:303-7. doi: 10.4103/0970-9185.117045

139. Remy C, Marret E, Bonnet F. Effects of Acetaminophen on Morphine SideEffects and Consumption After Major Surgery: Meta-Analysis of Randomized Controlled Trials $\uparrow \uparrow$ Presented in Part at the Annual Meeting of the Société Française d'anesthésie-Réanimation, Paris, April 2004. Br J Anaesthesia (2005) 94:505-13. doi: 10.1093/bja/aei085

140. Cherny N, Ripamonti C, Pereira J, Davis C, Fallon M, McQuay H, et al. Strategies to Manage the Adverse Effects of Oral Morphine: An Evidence-Based Report. J Clin Oncol (2001) 19:2542-54. doi: 10.1200/JCO.2001.19.9.2542

141. Zernikow B, Lindena G. Long-Acting Morphine for Pain Control in Paediatric Oncology. Med Pediatr Oncol (2001) 36:451-8. doi: 10.1002/mpo.1109

142. Liu X-Y, Liu Z-C, Sun Y-G, Ross M, Kim S, Tsai F-F, et al. Unidirectional Cross-Activation of GRPR by MOR1D Uncouples Itch and Analgesia Induced by Opioids. Cell (2011) 147:447-58. doi: 10.1016/j.cell.2011.08.043

143. Liu R, Wang J, Zhao T, Cao J, Che D, Ma P, et al. Relationship Between MRGPRX2 and Pethidine Hydrochloride- or Fentanyl Citrate-Induced LAD2 Cell Degranulation. J Pharm Pharmacol (2018) 70:1596-605. doi: 10.1111/jphp.13009

144. Dinges HC, Otto S, Stay DK, Bäumlein S, Waldmann S, Kranke P, et al. Side Effect Rates of Opioids in Equianalgesic Doses via Intravenous PatientControlled Analgesia: A Systematic Review and Network Meta-Analysis. Anesth Analg (2019) 129:1153-62. doi: 10.1213/ANE.0000000000003887

145. Reich A, Szepietowski JC. Opioid-Induced Pruritus: An Update. Clin Exp Dermatol (2010) 35:2-6. doi: 10.1111/j.1365-2230.2009.03463.x

146. Rosow CE, Moss J, Philbin DM, Savarese JJ. Histamine Release During Morphine and Fentanyl Anesthesia. Anesthesiology (1982) 56:93-6. doi: 10.1097/00000542-198202000-00003

147. Philbin DM, Moss J, Akins CW, Rosow CE, Kono K, Schneider RC, et al. The Use of $\mathrm{H} 1$ and $\mathrm{H} 2$ Histamine Antagonists With Morphine Anesthesia: A Double-Blind Study. Anesthesiology (1981) 55:292-6. doi: 10.1097/ 00000542-198109000-00019

148. Wong KC, Wayne WE, Hornbein TF, Everett J. The Cardiovascular Effects of Morphine Sulfate With Oxygen and With Nitrous Oxide in Man. Anesthesiology (1973) 38:542-9. doi: 10.1097/00000542-197306000-00007

149. Hsu HO, Hickey RF, Forbes AR. Morphine Decreases Peripheral Vascular Resistance and Increases Capacitance in Man. Anesthesiology (1979) 50:98102. doi: $10.1097 / 00000542-197902000-00005$

150. Fahmy NR, Sunder N, Soter NA. Role of Histamine in the Hemodynamic and Plasma Catecholamine Responses to Morphine. Clin Pharmacol Ther (1983) 33:615-20. doi: 10.1038/clpt.1983.83

151. Kaliner M, Shelhamer JH, Ottesen EA. Effects of Infused Histamine: Correlation of Plasma Histamine Levels and Symptoms. J Allergy Clin Immunol (1982) 69:283-9. doi: 10.1016/S0091-6749(82)80005-5 
152. Afshari R, Maxwell SRJ, Webb DJ, Bateman DN. Morphine Is an Arteriolar Vasodilator in Man. Br J Clin Pharmacol (2009) 67:386-93. doi: 10.1111/ j.1365-2125.2009.03364.x

153. Long WF, Taylor RJ, Wagner CJ, Leavengood DC, Nelson HS. Skin Test Suppression by Antihistamines and the Development of Subsensitivity. J Allergy Clin Immunol (1985) 76:113-7. doi: 10.1016/0091-6749(85) 90813-9

154. Levy JH, Brister NW, Shearin A, Ziegler J, Hug CC Jr, Adelson DM, et al. Wheal and Flare Responses to Opioids in Humans. Anesthesiology (1989) 70:756-60. doi: 10.1097/00000542-198905000-00008

155. Taylor RJ, Long WF, Nelson HS. The Development of Subsensitivity to Chlorpheniramine. J Allergy Clin Immunol (1985) 76:103-7. doi: 10.1016/ 0091-6749(85)90811-5

156. Casale TB, Bowman S, Kaliner M. Induction of Human Cutaneous Mast Cell Degranulation by Opiates and Endogenous Opioid Peptides: Evidence for Opiate and Nonopiate Receptor Participation. J Allergy Clin Immunol (1984) 73:775-81. doi: 10.1016/0091-6749(84)90447-0

157. Stefano GB, Hartman A, Bilfinger TV, Magazine HI, Liu Y, Casares F, et al. Presence of the $\mu 3$ Opiate Receptor in Endothelial Cells. J Biol Chem (1995) 270:30290-3. doi: 10.1074/jbc.270.51.30290

158. Saucedo R, Erill S. Morphine-Induced Skin Wheals: A Possible Model for the Study of Histamine Release. Clin Pharmacol Ther (1985) 38:365-70. doi: 10.1038/clpt.1985.189

159. Maurer U, Kager C, Fellinger C, Loader D, Pollesböck A, Spitzer B, et al. Risk of Anaphylaxis in Opioid Dependent Persons: Effects of Heroin Versus Substitution Substance. Subst Abuse Treatment Prevention Policy (2014) 9:12. doi: 10.1186/1747-597X-9-12

160. Collins S, Faura C, Moore RA, McQuay H. Peak Plasma Concentrations After Oral Morphine. J Pain Symptom Manage (1998) 16:388-402. doi: 10.1016/S0885-3924(98)00094-3

161. Pauli-Magnus C. Pharmacokinetics of Morphine and its Glucuronides Following Intravenous Administration of Morphine in Patients Undergoing Continuous Ambulatory Peritoneal Dialysis. Nephrol Dialysis Transplant (1999) 14:903-9. doi: 10.1093/ndt/14.4.903

162. Portenoy RK, Thaler HT, Inturrisi CE, Friedlander-Klar H, Foley KM. The Metabolite Morphine-6-Glucuronide Contributes to the Analgesia Produced by Morphine Infusion in Patients With Pain and Normal Renal Function. Clin Pharmacol Ther (1992) 51:422-31. doi: 10.1038/clpt.1992.42

163. Dale O, Thoner J, Nilsen T, Tveita T, Borchgrevink PC, Klepstad P. Serum and Cerebrospinal Fluid Morphine Pharmacokinetics After Single Doses of Intravenous and Intramuscular Morphine After Hip Replacement Surgery. Eur J Clin Pharmacol (2007) 63:837-42. doi: 10.1007/s00228-007-0329-x

164. Crews KR, Murthy BP, Hussey EK, Passannante AN, Palmer JL, Maixner W, et al. Lack of Effect of Ondansetron on the Pharmacokinetics and Analgesic Effects of Morphine and Metabolites After Single-Dose Morphine Administration in Healthy Volunteers. Br J Clin Pharmacol (2001) 51:30916. doi: 10.1046/j.1365-2125.2001.01369.x

165. Dershwitz M, Walsh JL, Morishige RJ, Connors PM, Rubsamen RM, Shafer SL, et al. Pharmacokinetics and Pharmacodynamics of Inhaled Versus Intravenous Morphine in Healthy Volunteers. Anesthesiology (2000) 93:619-28. doi: 10.1097/00000542-200009000-00009

166. Hand CW, Moore RA, McQuay HJ, Allen MC, Sear JW. Analysis of Morphine and its Major Metabolites by Differential Radioimmunoassay. Ann Clin Biochem: Int J Lab Med (1987) 24:153-60. doi: 10.1177/ 000456328702400205

167. Pham TDM, Ziora ZM, Blaskovich MAT. Quinolone Antibiotics. MedChemComm (2019) 10:1719-39. doi: 10.1039/C9MD00120D

168. Marchant J. When Antibiotics Turn Toxic. Nature (2018) 555:431-3. doi: 10.1038/d41586-018-03267-5

169. Stahlmann R, Lode H. Toxicity of Quinolones. Drugs (1999) 58:37-42. doi: 10.2165/00003495-199958002-00007

170. Owens RC, Ambrose PG. Antimicrobial Safety: Focus on Fluoroquinolones. Clin Infect Dis (2005) 41:S144-57. doi: 10.1086/428055

171. F. a. D. Administration. (2018) 2020.

172. McGee EU, Samuel E, Boronea B, Dillard N, Milby MN, Lewis SJ. Quinolone Allergy. Pharmacy (2019) 7:97. doi: 10.3390/pharmacy7030097

173. Yarrington ME, Anderson DJ, Dodds Ashley E, Jones T, Davis A, Johnson M, et al. Impact of FDA Black Box Warning on Fluoroquinolone and Alternative
Antibiotic Use in Southeastern US Hospitals. Infection Control Hosp Epidemiol (2019) 40:1297-300. doi: 10.1017/ice.2019.247

174. Ball P, Stahlmann R, Kubin R, Choudhri S, Owens R. Safety Profile of Oral and Intravenous Moxifloxacin: Cumulative Data From Clinical Trials and Postmarketing Studies. Clin Ther (2004) 26:940-50. doi: 10.1016/S0149-2918 (04) $90170-1$

175. Reich A, Ständer S, Szepietowski J. Drug-Induced Pruritus: A Review. Acta Dermato Venereologica (2009) 89:236-44. doi: 10.2340/00015555-0650

176. Ren H, Li X, Ni Z-H, Niu J-Y, Cao B, Xu J, et al. Treatment of Complicated Urinary Tract Infection and Acute Pyelonephritis by Short-Course Intravenous Levofloxacin $(750 \mathrm{Mg} /$ Day) or Conventional Intravenous/Oral Levofloxacin (500 Mg/Day): Prospective, Open-Label, Randomized, Controlled, Multicenter, non-I. Int Urol Nephrol (2017) 49:499-507. doi: 10.1007/s11255-017-1507-0

177. Ball P. Ciprofloxacin: An Overview of Adverse Experiences. J Antimicrob Chemother (1986) 18 Suppl D:187-93. doi: 10.1093/jac/18.SD.187

178. Brunner M, Stabeta H, Möller JG, Schrolnberger C, Erovic B, Hollenstein U, et al. Target Site Concentrations of Ciprofloxacin After Single Intravenous and Oral Doses. Antimicrob Agents Chemother (2002) 46:3724-30. doi: 10.1128/AAC.46.12.3724-3730.2002

179. Wall GC, Taylor MJ, Smith HL. Prevalence and Characteristics of Hospital Inpatients With Reported Fluoroquinolone Allergy. Int J Clin Pharm (2018) 40:890-4. doi: 10.1007/s11096-018-0613-0

180. De Winter BY, van den Wijngaard RM, de Jonge WJ. Intestinal Mast Cells in Gut Inflammation and Motility Disturbances. Biochim Biophys Acta (2012) 1822:66-73. doi: 10.1016/j.bbadis.2011.03.016

181. Alim MA, Peterson M, Pejler G. Do Mast Cells Have a Role in Tendon Healing and Inflammation? Cells (2020) 9:1134. doi: 10.3390/cells9051134

182. Behzad H, Sharma A, Mousavizadeh R, Lu A, Scott A. Mast Cells Exert ProInflammatory Effects of Relevance to the Pathophyisology of Tendinopathy. Arthritis Res Ther (2013) 15:R184. doi: 10.1186/ar4374

183. Alves C, Mendes D, Marques FB. Fluoroquinolones and the Risk of Tendon Injury: A Systematic Review and Meta-Analysis. Eur J Clin Pharmacol (2019) 75:1431-43. doi: 10.1007/s00228-019-02713-1

184. Johannes CB, Ziyadeh N, Seeger JD, Tucker E, Reiter C, Faich G. Incidence of Allergic Reactions Associated With Antibacterial Use in a Large, Managed Care Organisation. Drug Saf (2007) 30:705-13. doi: 10.2165/00002018200730080-00007

185. Aminimanizani A, Beringer P, Jelliffe R. Comparative Pharmacokinetics and Pharmacodynamics of the Newer Fluoroquinolone Antibacterials. Clin Pharmacokinetics (2001) 40:169-87. doi: 10.2165/00003088-20014003000003

186. Schlender J-F, Teutonico D, Coboeken K, Schnizler K, Eissing T, Willmann S, et al. A Physiologically-Based Pharmacokinetic Model to Describe Ciprofloxacin Pharmacokinetics Over the Entire Span of Life. Clin Pharmacokinetics (2018) 57:1613-34. doi: 10.1007/s40262-018-0661-6

187. Fish DN, Chow AT. The Clinical Pharmacokinetics of Levofloxacin. Clin Pharmacokinetics (1997) 32:101-19. doi: 10.2165/00003088-199732020-00002

188. Mertes PM, Voiriot P, Dopff C, Scholl H, Clavey M, Villemot JP, et al. Penetration of Ciprofloxacin Into Heart Valves, Myocardium, Mediastinal Fat, and Sternal Bone Marrow in Humans. Antimicrobial Agents Chemotherapy (1990) 34:398-401. doi: 10.1128/AAC.34.3.398

189. Gotfried MH, Danziger LH, Rodvold KA. Steady-State Plasma and Intrapulmonary Concentrations of Levofloxacin and Ciprofloxacin in Healthy Adult Subjects. Chest (2001) 119:1114-22. doi: 10.1378/chest.119.4.1114

190. Furlanut M. Pharmacokinetic Aspects of Levofloxacin 500 Mg Once Daily During Sequential Intravenous/Oral Therapy in Patients With Lower Respiratory Tract Infections. J Antimicrobial Chemotherapy (2003) 51:1016. doi: $10.1093 / \mathrm{jac} / \mathrm{dkg} 035$

191. Chow AT, Fowler C, Williams RR, Morgan N, Kaminski S, Natarajan J. Safety and Pharmacokinetics of Multiple 750-Milligram Doses of Intravenous Levofloxacin in Healthy Volunteers. Antimicrobial Agents Chemotherapy (2001) 45:2122-5. doi: 10.1128/AAC.45.7.2122-2125.2001

192. Yan A, Bryant EE. Statpearls. Treasure Island (FL: StatPearls PublishingCopyright @ 2 2020, StatPearls Publishing LLC. (2020).

193. Rodvold KA, Neuhauser M. Pharmacokinetics and Pharmacodynamics of Fluoroquinolones. Pharmacotherapy (2001) 21:233S-52S. doi: 10.1592/ phco.21.16.233S.33992 
194. Perletti G, Wagenlehner FME, Naber KG, Magri V. Enhanced Distribution of Fourth-Generation Fluoroquinolones in Prostatic Tissue. Int J Antimicrobial Agents (2009) 33:206-10. doi: 10.1016/j.jantimicag.2008.09.009

195. Kiem S, Schentag JJ. Interpretation of Antibiotic Concentration Ratios Measured in Epithelial Lining Fluid. Antimicrobial Agents Chemotherapy (2008) 52:24-36. doi: 10.1128/AAC.00133-06

196. Soman A, Honeybourne D, Andrews J, Jevons G, Wise R. Concentrations of Moxifloxacin in Serum and Pulmonary Compartments Following a Single $400 \mathrm{Mg}$ Oral Dose in Patients Undergoing Fibre-Optic Bronchoscopy. J Antimicrobial Chemotherapy (1999) 44:835-8. doi: 10.1093/jac/44.6.835

197. Kato M. Chondrotoxicity of Quinolone Antimicrobial Agents. $J$ Toxicol Pathol (2008) 21:123-31. doi: 10.1293/tox.21.123

198. Hall MM, Finnoff JT, Smith J. Musculoskeletal Complications of Fluoroquinolones: Guidelines and Precautions for Usage in the Athletic Population. PMぬR (2011) 3:132-42. doi: 10.1016/j.pmrj.2010.10.003
Conflict of Interest: The author declares that the research was conducted in the absence of any commercial or financial relationships that could be construed as a potential conflict of interest.

Publisher's Note: All claims expressed in this article are solely those of the authors and do not necessarily represent those of their affiliated organizations, or those of the publisher, the editors and the reviewers. Any product that may be evaluated in this article, or claim that may be made by its manufacturer, is not guaranteed or endorsed by the publisher.

Copyright $(\odot) 2021$ McNeil. This is an open-access article distributed under the terms of the Creative Commons Attribution License (CC BY). The use, distribution or reproduction in other forums is permitted, provided the original author(s) and the copyright owner(s) are credited and that the original publication in this journal is cited, in accordance with accepted academic practice. No use, distribution or reproduction is permitted which does not comply with these terms. 